\title{
Desain Interior Dan Eksterior Dalam Usaha Pencegahan Penyebaran Covid-19 Di Kantor Desa Pemecutan Kaja, Kota Denpasar
}

\author{
Cok Gd Rai Padmanaba, A.A Putu Fajar Arika Harry Putra
}

Program Studi Desain Interior, Fakultas Seni Rupa dan Desain, Institut Seni Indonesia Denpasar.

cokraip@gmail.com,fajararika@gmail.com

Sosialisasi tatanan normal baru yang sudah dicanangkan oleh Kementerian Kesehatan, perlu dilaksanakan secara masif sehingga masyarakat tahu apa yang harus dikerjakan baik mengenai jaga jarak, memakai masker, mencuci tangan, dan dilarang berkerumun dalam jumlah yang banyak. Bali sebagai salah satu wilayah NKRI, tentunya juga harus tunduk pada aturan tersebut, dengan menerapkan protokol tatanan normal baru, di berbagai segi kehidupan masyarakat, termasuk juga kantor-kantor pelayanan masyarakat. Di lain sisi, pada bulan Agustus 2020, Institut Seni Indonesia Denpasar menyelenggarakan program Kuliah Kerja Nyata secara mandiri, yang dilakukan di lokasi kediaman masing-masing mahasiswa, karena pada bulan tersebut masih dalam masa pandemi Covid-19 di Bali. Salah satu program kerja yang dilakukan adalah mendesain interior dan eksterior Kantor Desa Pemecutan Kaja, karena kantor ini harus tetap melayani kepentingan administrasi masyarakat desa, pada masa pandemi covid-19 dengan tetap menerapkan protokol Kesehatan. Adapun metode yang diterapkan pada penelitian ini adalah Teori Fungsi menurut Victor Papanex, yang meliputi Kebutuhan, Asosiasi, Telesik, Metode, Estetika dan kegunaan. Pada tahap desain, metode di atas juga dipadukan dengan metode Panca Sthiti Ngawi Sani, sebagai metodologi penciptaan seni, yang terdiri dari lima tahapan, yaitu; Tahap inspirasi, tahap eksplorasi, tahap konsepsi, tahap eksekusi dan tahap ngebah. Hasil dari penelitian ini adalah desain secara menyeluruh di area Kantor, mulai dari penempatan dan desain wash tafel di halaman kantor, sampai desain tata letak dan desain kursi, meja, counter, dan alur sirkulasi dalam kantor. Dengan desain ini, diharapkan mampu membantu pencegahan penyebaran covid-19 di area kantor desa Pemecutan Kaja.

\section{Kata Kunci.: Desain interior, Eksterior, Covid-19.}

The socialization of the new normal order that has been programmed by the Ministry of Health needs to be carried out massively so that the public knows what to do, whether it is to maintain distance, wear masks, wash hands, and prohibit large crowds. Bali as one of the areas of the Republic of Indonesia, of course, must also comply with these regulations, by implementing the new normal order protocol, in various aspects of community life, including community service offices. On the other, in August 2020, the Indonesian Institute of the Arts Denpasar organized an independent Real Work Lecture program, which was conducted at the residence location of each student, because that month was still in the period of the Covid-19 pandemic in Bali. One of the work programs carried out is designing the interior and exterior of the Pemecutan Kaja Village Office, because this office must continue to serve the administrative interests of the village community, during the Covid-19 pandemic by still implementing the Health protocol. The method applied in this research is Function Theory according to Victor Papanex, which includes Needs, Associations, Telesics, Methods, Aesthetics and Usability. At the design stage, the above method is also combined with the Panca Sthiti Ngawi Sani method, as a methodology for art creation, which consists of five stages, namely; The inspiration stage, the exploration stage, the conception stage, the execution stage and the ngebah stage. The result of this research is a comprehensive design in the office area, starting from the placement and design of the wash tafel in the office yard, to the layout and design of chairs, tables, counters, and circulation flow in the office. With this design, it is expected to be able to help 
prevent the spread of Covid-19 in the Pemecutan Kaja village office area.

Keywords: interior design, exterior, Covid-19.

Proses review: 1 - 4 Mei 2021, Dinyatakan lolos 5 Mei 2021

\section{PENDAHULUAN}

Guna mencegah situasi ekonomi Indonesia semakin tidak kondusif, dalam rapat terbatas pada tanggal 27 Mei 2020, Presiden Jokowi meminta agar dilakukan sosialisasi kepada masyarakat tentang protokol tananan normal baru."Tatanan normal baru yang sudah disiapkan oleh Kementerian Kesehatan ini agar disosialisasikan secara masif sehingga masyarakat tahu apa yang harus dikerjakan baik mengenai jaga jarak, memakai masker, mencuci tangan, dan dilarang berkerumun dalam jumlah yang banyak," ujar Presiden. Aturan normal baru di perkantoran dan industri telah diterbitkan Menkes Terawan melalui Keputusan Menteri Kesehatan (KMK) Nomor HK.01.07/MENKES/328/2020 tentang Panduan Pencegahan dan Pengendalian Covid-19 di Tempat Kerja Perkantoran dan Industri dalam Mendukung Keberlangsungan Usaha pada Situasi Pandemi. (Kompas.com, 2020/05/27 "New Normal di Indonesia, Apa yang Akan Terjadi?”, )

Kebijakan pemerintah untuk menerapkan normal baru ini diharap berbarengan dengan kesadaran masyarakat untuk tetap menjaga protokol kesehatan secara ketat sebab covid-19 pada bulan Agustus, September ada kecenderungan mengalami peningkatan.

Bali sebagai salah satu wilayah NKRI, tentunya juga harus tunduk pada aturan tersebut. dengan menerapkanprotokoltatanannormalbaru, diberbagai segi kehidupan masyarakat, termasuk juga kantorkantor pelayanan masyarakat. Di lain pihak, pada bulan Agustus 2020, Institut Seni Indonesia Denpasar menyelenggarakan program Kuliah Kerja Nyata secara mandiri, yang dilakukan di lokasi kediaman masing-masing mahasiswa, mengingat pada bulan tersebut masih dalam masa pandemi Covid-19 di Bali. Berpijak dari permasalahan ini, maka salah seorang mahasiswa Desain Interior Fakultas Seni Rupa dan Desain Institut Seni Indonesia Denpasar, yang bertempat tinggal di wilayah Desa Pemecutan Kaja, menyampaikan program Kerja "Peran Desain Interior Dalam Usaha Pencegahan Pandemi Covid 19 Di Kantor Kepala Desa Pemecutan Kaja, Kecamatan Denpasar Utara, Kota Madya Denpasar.”. Dipilihnya kantor Desa sebagai objek, karena kantor ini harus tetap melayani kepentingan administrasi masyrakat desa, namun harus tetap menerapkan protokol Kesehatan.

Kantor Desa Pemecutan Kaja merupakan pusat pelayanan publik bagi masyarakat desa. Menjadi central bagi segala kegiatan yang ada di desa tersebut. Kantor desa ini berada di daerah Denpasar utara dengan memiliki luas wilayah $3,85 \mathrm{~km}^{2}$.Dimasa pandemi covid-19 ini Kantor desa harus menerapkan sistem fasilitas protokol guna dapat memutus rantai penyebaran virus ini, maka diperlukan penataan yang sesuai dengan standar protokol kesehatan yang berlaku. Pada lokasi kasus terdapat beberapa bagian kantor yang belum memenuhi standar protokol seperti jarak pada ruang pegawai sampai area resepsionis yang belum memakai dinding protokol mengakibatkan penyebaran virus mungkin bisa terjadi.

Melalui kegiatan pengabdian pada masyarakat Kuliah Kerja Nyata ini, ini diharapkan mampu membantu mengembangkan potensi dari desa tersebut melalui desain interior yang baik dan sesuai protokol, kesehatan sehingga dapat mencegah penyebaran Covid -19.

\section{METODE PENCIPTAAN}

Penelitian Penciptaan/Perancangan karya ini mepergunakan teori Fungsi menurut Victor Papanex, yang meliputi Kebutuhan (need), Asosiasi (association), Telesik (telesis), Metode (method), Estetika (aesthetics), dan kegunaan (use). (Hendriyana, 2018) Adapun implenetasi dari teori Fungsi ini dimulai dari pendataan terhadap kebutuhan ruang gerak dari pemakai ruang. Kemudian dilanjutkan dengan menghubungkan ide 
dan data visual kedalam gambar gagasan, memaknai benda atau produk ke dalam dimensi sosial dan budaya. Selanjutnya menentukan metode yang melibatkan teori dan teknik yang akan diterapkan, dengan tidak meninggalkan unsur-unsur keindahan serta kegunaan dari hasil rancangan baik dalam beraktivitas, maupun dalam upaya pencegahan penyebaran Covid-19 pada kantor Desa. Pada tahap perancangan, metode di atas juga dipadukan dengan metode Panca Sthiti Ngawi Sani, sebagai metodologi penciptaan seni, yang terdiri dari lima tahapan, yaitu; Tahap inspirasi, (Ngawirasa), tahap Eksplorasi (Ngawacak), tahap konsepsi (Ngarencana), tahap Eksekusi (Ngawangun) dan tahap Ngebah (Maedeng). (Dibia, 2020. Implementasi metode ini dilakukan dengan menjadikan aturan tatanan normal baru sebagai pemicu inspirasi, kemudian mengeplorasi ide dan gagasan, sesuai dengan konsep yang dipakai, sehingga menghasilkan karya Desain interior. Hasil rancangan ini kemudian diperlihatkan kepada kepala desa dan staff sambil dijelaskan tentang segala hal yang ada pada rancangan tersebut.

\section{PROSES PERWUJUDAN}

Pada proses perwujudan desain interior dan eksterior kantor desa ini melalui lima tahapan, seperti yang disampaikan pada metode Panca Sthiti Ngawi Sani, yaitu 1. Tahap inspirasi, (Ngawirasa), dimana desainer melakukan penjajagan dan observasi lapangan, serta melihat beberapa contoh desain interior kantor untuk mendapatkan data sebagai pijakan pemikiran dan inspirasi pembuatan desain. Langkah selanjutnya adalah tahap 2, yaitu Eksplorasi (Ngawacak), dengan mencari beberapa gambar desain dan teori, baik bentuk, bahan, warna dan sebagainya, untuk dikembangkan dalam desain. Mencari data tentang kebutuhan ruang dan fasilitas dari semua pengguna ruang yang akan beraktivitas di Kantor Desa Pemecutan Kaja. Melalui pengukuran, wawancara dan dokumen-dokumen desa yang diperlukan. Seperti gambar berikut.

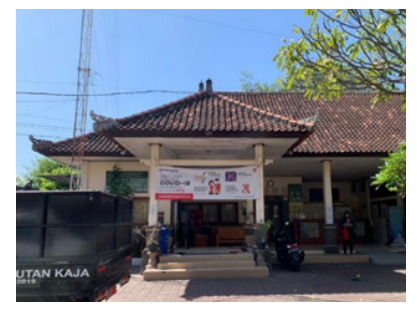

Gambar 1. Kantor Desa Pemecutan Kaja

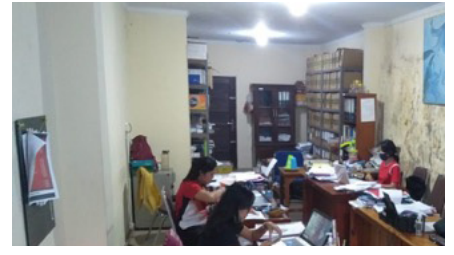

Gambar 2. Proses mencari data lapangan

Setelah melalui tahap survey, pengukuran dan wawancara dengan Kepala Desa, maka didapatkan bahwa pada kantor ini memerlukan tempat pencuci tangan di halaman kantor dengan desain dan posisi yang informatif bagi masyarakat pengunjung. Demikian juga pada interior memerlukan pemecahan masalah terhadap jarak duduk pengunjung di ruang tunggu, keamanan interaksi antara staff dan pengunjung serta penataan ruang rapat, ruang perpustakaan dan lobby kantor. Proses Selanjutnya adalah tahap 3, Konsepsi (Ngarencana), dimana desainer mulai merencanakan desain berdasarkan hasil analisisnya. Proses pengerjaan kebutuhan dokumen data yang akan digunakan sebagai acuan dalam mendesain, yang pertama adalah matrix hubungan ruang untuk menentukan jarak ruangnya. Kemudian menentukan zonasi yang baik bagi kantor desa agar mempermudah dalam menentukan blok bagian ruang, berikutnya adalah proses menentukan blok plan dari kantor desa agar pembagian setiap bagian ruangnya dapat tertata dengan baik. Pada tahap ini desain dikerjakan dengan program AutoCAD, karena masih berupa gambar 2 dimensi.

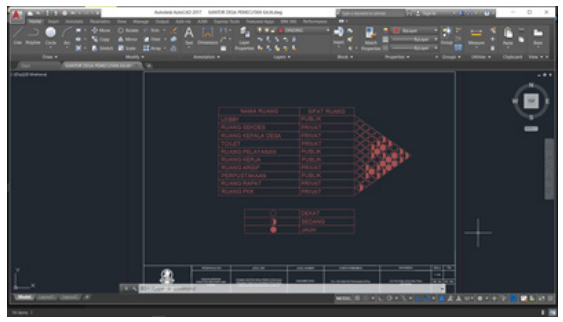

Gambar 3. Proses Matrix Hubungan ruang dengan program AutoCAD

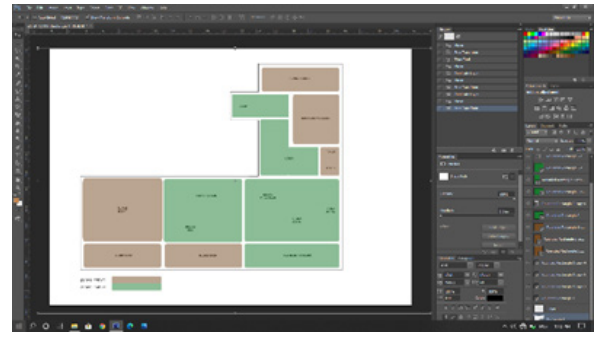

Gambar 4. Proses Zonasi Ruang dengan program AutoCAD 
Selanjutnya adalah proses menentukan blok plan dari kantor desa agar pembagian setiap bagian ruangnya dapat tertata dengan baik. Proses berikutmnya yaitu membuat layout dari kantor desa ini menjadi dasar menuju proses konseptual design, dilengkapi dengan posisi bukaan ruang serta jalur sirkulasi sesuai dengan hasil program matrix hubungan ruang. Untuk penggambaran blok plan dan lay lay out ini masih mempergunakan program AutoCAD

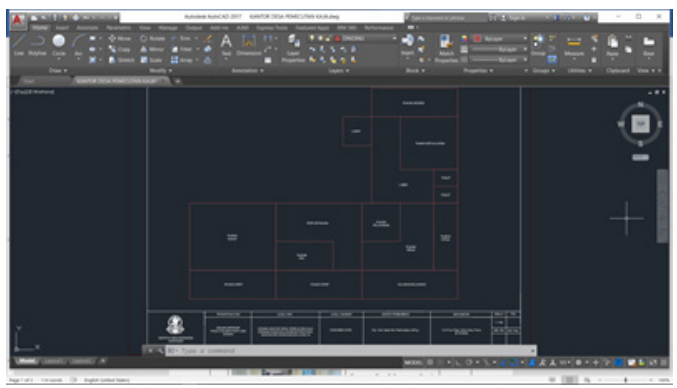

Gambar 5. Proses Blok plan dengan program AutoCAD

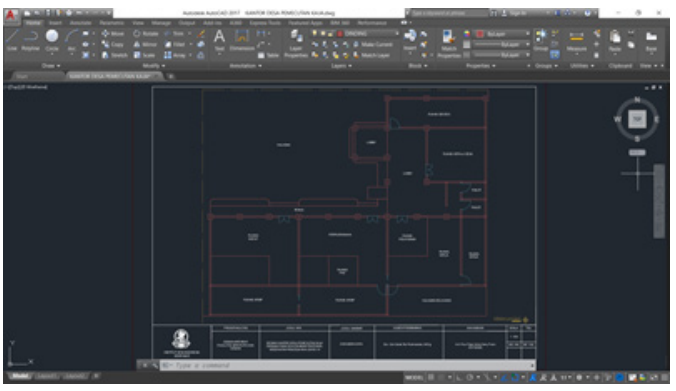

Gambar 6. Proses Lay Out dengan program AutoCAD

Proses pengerjaan desain konsepsual dimulai dengan pembuatan objek 3D dari kantor desa dengan program ScetchUp, dan Enscape Di tahap ini dilakukan peletakan fasilitas protokol covid-19 serta penataan ruang kerja yang sesuai dengan protocol Kesehatan. Setelah pengerjaan objek 3D maka dilakukan proses rendering objek view pada setiap bagian yang dibutuhkan untuk memvisualkan bentuk dari desain itu sendiri. Pada tahap ini dilakukan untuk mendapatkan view dari penataan, fasad, aksonometri, hingga perspektif setiap bagian ruangnya, yang dimulai dari layout dari kantor desa ini menjadi dasar menuju proses konsepsual design, bukaan serta jalur di desain agar memudahkan efisiensi waktu saat bekerja. Pada tahap ini dirancang penempatan wash tafel di halaman kantor, untuk memberikan edukasi kepada masyarakat tentang pentingnya mencuci tangan sebelum dan sesudah memasuki ruangan. Pada interior perancangan diutamakan pada hal-hal yang bisa mengantisipasi penularan Covid-19 di dalam ruangan, dengan cara mendesain kursi tunggu yang berjarak sesuai dengan ketentuan protocol Kesehatan, dan tetap berpedoman pada asas ergonomi agar bisa dipakai secara nyaman, sehingga penerapan ergonomi juga sangat perlu diperhatikan. Ergonomi berkenaan pula dengan optimasi, efisiensi, Kesehatan, keselamatan dan kenyamanan manusia di tempat kerja,( Nurmianto. E., 1998:1)Demikian juga pengaturan letak kursi bagi Kepala desa dan staffnya, pada ruang kerja, ruang rapat, serta mengatur sirkulasi lalu lintas yang terjadi dalam ruangan agar mempunyai jarak yang cukup aman. Pada counter pelayanan masyarakat, dilengkapi dengan penyekat mika transparan, agar tidak terjadi kontak langsung antara masyarakat dengan staff yang melayani. Setelah terbentuk gambar 3D maka selanjutnya dilakukan proses rendering animasi $3 \mathrm{~d}$ kantor desa, pada setiap view bagian ruaangnya satu persatu disusul dengan proses editing scane animasi yang telah dirender dan kemudian dijadikan satu buah animasi lengkap berisi seluruh view $3 \mathrm{D}$ kantor desa,

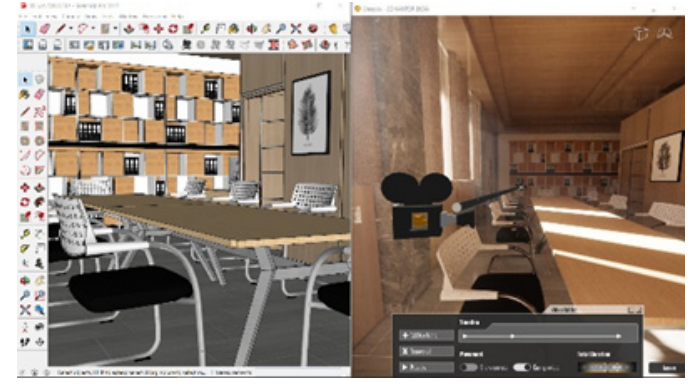

Gambar 7. Proses rendering animasi 3D Kantor Desa

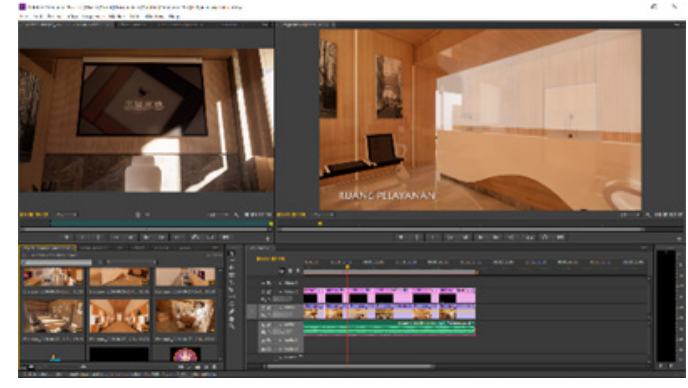

Gambar 8. Proses editing scane animasi yang telah dirender

\section{WUJUD KARYA.}

Dari rangkaian proses perwujudan yang diuraikan di atas, dilanjutkan dengan proses ke 4 yaitu tahap Eksekusi (Ngawangun) yang berupa desain 3D lay out kantor desa seperti terlihat pada gambar berikut: 


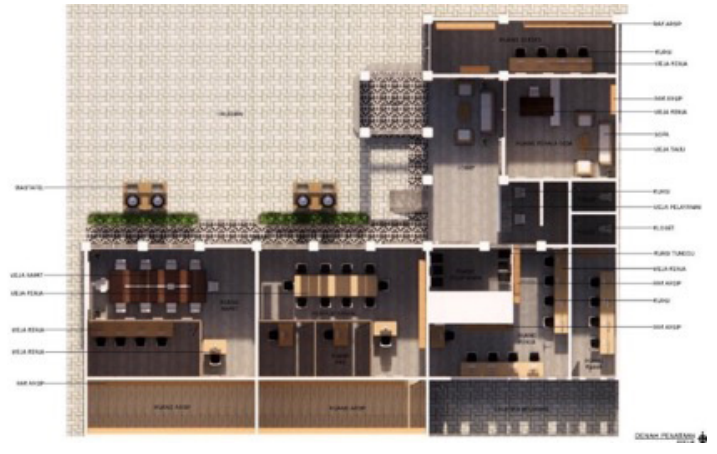

Gambar 9. Denah Penataan Eksterior dan Interior Kantor Desa Pemecutan Kaja

Beberapa penerapan desain penataan serta fasilitas protokol yang diterapkan pada desain kantor desa ini, merupakan hal penting dan perlu menjadi perhatian dalam proses perancangannya. Adapun penerapan protokol Kesehatan seperti penempatan wastafel outdoor hingga penataan ruang kerja yang mencegah kontak fisik secara langsung. Sirkulasi dan zonasi ruang juga dilakukan perubahan agar memaksimalkan civitas dalam melakukan kegiatan.

Dengan proses perancangan menggunakan software seperti AutoCAD, ScetchUp, dan Enscape , proses desain dilanjutkan sehingga mengahasilkan gambar gambar3Dyanglebih mudah dimengertikarenawujud desain sudah bisa dilihat maksudnya. Penerapan program ini diharapkan mampu memaksimalkan hasil gambar kerja yang dapat memvisualkan ide dari desainer maupun dari pihak kantor desa. Pada bagian eksterior kantor desa diterapkan 4 jumlah wastafel yang masing-masing diletakkan terpisah agar menghindari penumpukan antrean saat proses pencucian tangan, sekat juga dipasang pada bagian tengah watafel untuk menghindari kontak fisik secara langsung antar civitas. Sedangkan pada ruang tunggu, kursi didesin sedemikian rupa agar masyarakat yang menunggu secara langsung menjaga jarak pada sat duduk, karena tempat duduk didersain berjarak.

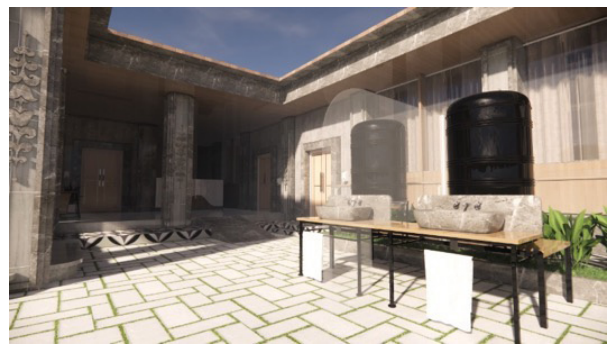

Gambar 10. Desain dan Penempatan Wash tafel tempat mencuci tangan di halaman kantor

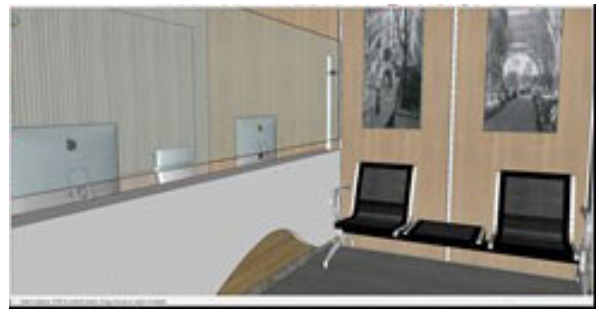

Gambar 11. Desain kursi tunggu yang dibuat berjarak

Pada bagian meja pelayanan juga menggunakan sekat pemisah antara pengunjung dengan pegawai kantor. Ruang kerja sebelumnya yang menyatu antar pegawai sehingga memungkinkan kontak fisik secara langsung, dengan penerapan penataan ruang kerja seperti gambar yang memisahkan antar pegawai kantor dengan sekat dapat lebih efektif dalam melakukan aktifitas, serta dapat menghindari kontak fisik secara langsung. Setelah proses desain juga berdampak pada kesan ruangan yang ditimbulkan seperti lebih terasa luas dan leluasa dalam beraktifitas.

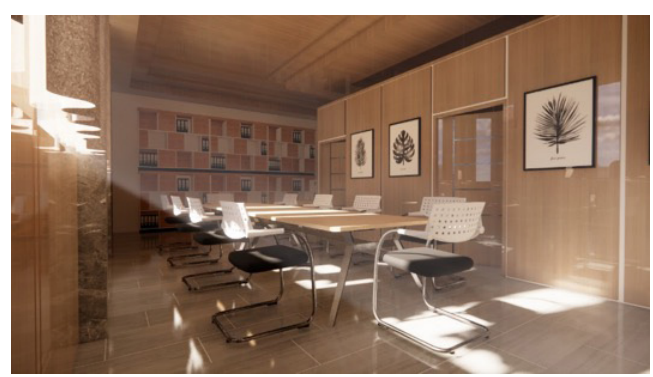

Gambar 12. Ruang Perpustakaan dengan kursi yang berjarak

Beberapa penerapan jarak duduk antar staf juga diterapkan diberbagai ruangan yang memiliki fungsi sebagai tempat berkumpul staf kantor desa seperti ruang perpustakaan hingga ruang rapat. Pada setiap bagian depan ruangan juga diberikan Hand Sanitizer agar memudahkan bagi setiap civitas yang masuk untuk melakukan tahapan protokol terlebih dahulu.

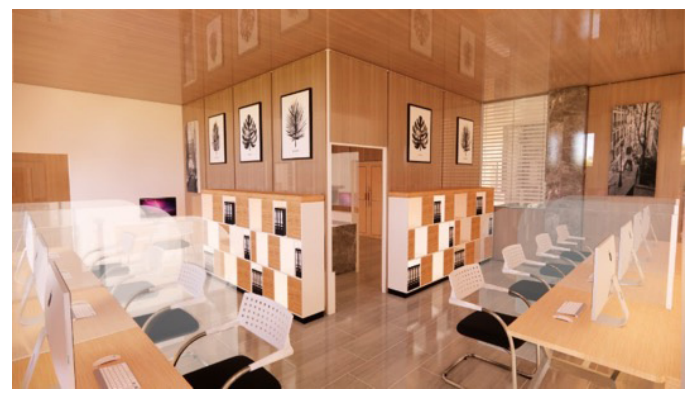

Gambar 13. Ruang Kerja dengan penyekat antara pegawai 
Pada kegiatan akhir KKN adalah tahapan terakhir dari metode Panca Sthiti Ngawi Sani, yaitu tahap ke 5. Ngebah (Maedeng), merupakan penyerahan hasil desain kantor desa kepada kepala desa,serta staf yang berwenang yang akan digunakan sebagai arsip kedepannya. Hasil Desain diperlihatkan dan diserahkan kepada pihak kantor Kepala Desa Pemecutan Kaja.Dari pihak kantor desa memberikan tanggapan yang sangat positif bagi karya desain mahasiswa KKN ini, tidak hanya memperhatikan protokol kesehatan tetapi juga melakukan pembaharuan pada setiap bagian ruangannya. Sehingga para pegawai serta staf dapat merasa lebih nyaman dalam berkerja maupun melakukan aktifitas lainnya.

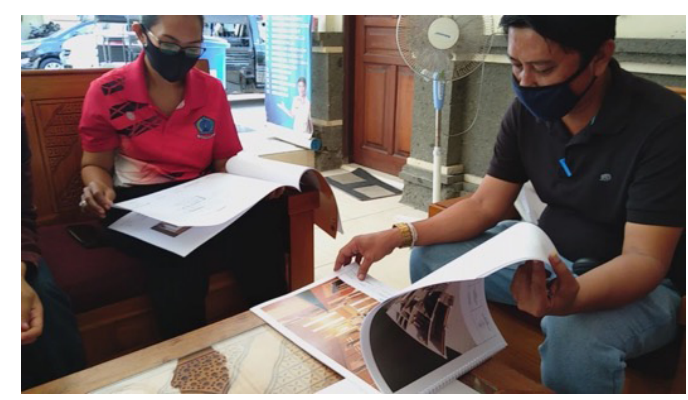

Gambar 14. Suasana Penyerahan hasil gambar Desain Kantor Desa, Pemecutan Kaja

\section{SIMPULAN}

Pada masa pandemi Covid-19 ini seluruh ruang pelayanan publik wajib menerapkan standar protokol kesehatan seperti wastafel hingga hand sanitizer, agar dapat memutus rantai penyebaran virus ini. Penataan ruang pelayanan serta ruang kerja juga hal yang perlu diperhatikan, dikarenakan pembatasan seperti sekat dan jarak juga harus diterapkan agar menghindari kontak fisik secara langsung. Hal ini perlu diterapkan disetiap bagian ruangnya yang berpotensi menjadi penyebaran virus Covid-19 ini. Program KKN yang dilaksanakan oleh mahasiswa ISI Denpasar ini diharapkan dapat membantu memberi keamanan dan kenyamanan yang baik kepada masyarakat Desa Pemecutan Kaja dengan adanya desain penataan ruang yang baik yang sesuai dengan standar protokol kesehatan Covid-19 pada saat ini. Desain yang diterapkan merupakan inovasi dalam hal pencegahan penyebaran virus Covid-19 pada tempat pelayanan publik. Masyarakat yang berkunjung dan staff yang melayani juga dapat merasa lebih tenang dengan penerapan penataan protokol Kesehatan ini, melalui hasil Desain interior dan eksterior, pada ruang, fasilitas dan halaman kantor Desa Pemecutan Kaja.

Dari pihak kantor desa juga memberikan tanggapan yang sangat positif bagi karya desain mahasiswa KKN ini, tidak hanya memperhatikan protokol kesehatan tetapi juga melakukan inovasi pada interior dan eksterior, sehingga para pengunjung serta staf dapat merasa lebih nyaman dalam berkerja maupun melakukan aktifitas lainnya.

\section{DAFTAR RUJUKAN}

Ching. F.D.K.1996. Ilustrasi Desain Interior. Jakarta: Penerbit Erlangga.

Dibia, I Wayan. (2020).Panca Sthiti Ngawi Sani, Metodologi Penciptaan Seni. Denpasar : Pusat Penerbitan LP2MPP ISI Denpasar.

Dinas Komunikasi, Informatika, dan Statistik. (2017). Sejarah Desa Pemecutan Kaja, https:// pemecutankaja.denpasarkota.go.id/page/ read/1644. (diunduh :1 September 2020)

Hakari, LM. (2014). Tata Ruang Kantor, http:// eprints.polsri.ac.id/782/3/FILE\%203.pdf. (diunduh 28 July 2020)

Hendriyana.H, 2018. Metodologi Penelitian Penciptaan Karya Seni Kriya \& Desain Produk Non Manufaktur, Bandung: Sunan Ambu Press.

Interior Kantor. 2006. "Pengaturan Ruang Kantor", https://interiorkantor.com/pengaturan-ruangkantor/. (28 July 2020)

Nurmianto. E. 1998. Ergonomi, Konsep Dasar dan Aplikasinya. Jakarta: Candimas Metropole.

Panero, J, Zelnik. M.1980. Human Dimension \& Interior Space. London: The Architectural Press Ltd.

Sugiharto. 2016. "Perancangan Perabot Kerja Kantor" , http://publication.petra.ac.id/index.php/desaininterior/article/viewFile/4651/4265. (28 July 2020) Wilkening. F. 1992. Tata Ruang:Semarang. Penerbit Kanisius. 